\title{
The Effects of Web Atmospherics on Entertainment Gratification and Web Irritation: Some Empirical Evidence from Online Shopping
}

\author{
Weng Marc Lim ${ }^{1}$ \\ ${ }^{1}$ School of Business, Monash University, Malaysia \\ Correspondence: Weng Marc Lim, School of Business, Monash University, Malaysia. E-mail: \\ lim.weng.marc@monash.edu
}

Received: August 29, 2013

Accepted: October 30, $2013 \quad$ Online Published: November 11, 2013

doi:10.5539/mas.v7n12p15

URL: http://dx.doi.org/10.5539/mas.v7n12p15

\begin{abstract}
The difficulty in converting web browsers into actual online customers remains a problem for many online retailers. While previous studies have suggested that online retailers should strive to increase entertainment gratification and reduce web irritation among online consumers, they lack empirical evidence to support the manipulation of web atmospherics toward this end. The research presented here establishes and tests the conceptual links of web atmospherics, entertainment gratification and web irritation. Data were collected using survey and mall-intercept systematic sampling approaches and analyzed using structural equation modeling. The results indicate that well-designed dynamic web atmospherics had a significant effect in increasing entertainment gratification and reducing web irritation. Implications and recommendations from the research findings are also presented.
\end{abstract}

Keywords: web atmospherics, entertainment gratification, web irritation, online shopping

\section{Introduction}

The Internet has gained considerable attention as an area for marketing and consumer behavior research (Lim, 2013). Of the many factors contributing to the exponential and significant increase in Internet usage, most researchers agree that the growth of Web content has made the most critical contribution (Huang, 2008; Leighton, 2009; Szabo \& Huberman, 2010). Unlike offline mediums of communication (e.g., print media [newspapers, magazines]), the Web (online medium of communication) possess characteristics of high connectivity, interactivity, and global reach (Mulhern, 2009; Scarpi, 2012; Singh, Bansal, \& Kaur, 2012). These characteristics have turned the Internet into a virtual marketplace, where interactive tools can enable businesses to build and strengthen relationships with consumers (Ko, Cho, \& Roberts, 2005).

A plethora of studies have been devoted to better understanding of consumer behavior on the Internet, including consumer characteristics (Lian \& Lin, 2008; Wu, 2003), decision-making (Darley, Blankson, \& Luethge, 2010; Kim, Ferrin, \& Rao, 2008), flow (Bridges \& Florsheim, 2008; Hoffman \& Novak, 2009), perceived risk (Chang \& Tseng, 2011; Chang \& Wu, 2012), purchasing behavior (Ahuja, Gupta, \& Raman, 2003; Hernandez, Jimenez, \& Martin, 2010), loyalty (Srinivasan, Anderson, \& Ponnavolu, 2002; Suh \& Yi, 2012), social interaction (Cheung, Chiu, \& Lee, 2011; Hess, Lang, \& Xu, 2011; Jing \& Xie, 2011), and technology acceptance (Ha \& Stoel, 2009; Lim \& Ting, 2012a).

Unfortunately, many websites fail to convert web visits into actual online purchases. Supporting this, Baymard Institute (2013), a web research institute, found that $67 \%$ of online shoppers drop out of their shopping carts without completing the transaction; this percentage value was an average, calculated on the basis of 22 different studies in 2012 containing statistics on electronic commerce shopping cart abandonment. While this latest statistic indicates a lower online consumer dropout rate compared to an earlier study by Kearney (2001) who reported an $82 \%$ of shopping cart abandonment rate, much more needs to be done by online retailers to further reduce the number of online consumer dropouts; failing to do so may inevitably lead to a recurrence of the dotcom failure of the 1990s.

Several other studies contend that these failures are the result of neglected consumer needs (Nielson, 2000; Hausman \& Siekpe, 2009). Huang (2008) highlighted that consumer motivation for online shopping is not only related to factors such as broader selection, competitive pricing, convenience, and easy access to information but 
also to entertainment and enjoyment. Lim and Ting (2012b) emphasized the criticality of creating a gratifying shopping experience and avoiding web irritation in shaping desirable consumer attitudes and behavior. While these studies recommended careful design of online shopping websites so as to provide a pleasurable online shopping experience, they lacked empirical evidence to support the anticipated effects of web atmospherics on entertainment gratification and web irritation.

Accordingly, research establishing the relationship among web atmospherics, entertainment gratification, and web irritation is urgently needed. Building on this research tradition, the present study addresses two critical issues. First, it investigates the effects of web atmospherics on entertainment gratification, in which an online retailer who is able to increase consumers' entertainment gratification, was empirically found to create positive consumer attitudes and behaviors toward online shopping (Huang, 2008; Lim \& Ting, 2012b). Second, this study examines the effects of web atmospherics on web irritation, in which online shopping sites that reduce consumers' web irritation were empirically reported to foster more favorable attitudes and behaviors toward online shopping among online consumers (Huang, 2008; Lim \& Ting, 2012b). The proposed model is evaluated in terms of overall model fit and causal links.

This paper is divided into the following five sections: a literature review and hypotheses development for web atmospherics, entertainment gratification, and web irritation; research design and methods; analysis of empirical data; discussion of results; limitations of the study and suggestions for future research.

\section{Literature Review and Hypotheses Development}

\subsection{Web Atmospherics}

A proliferation of online shopping websites has made online retailers rather similar to one another in terms of their market offerings (e.g. products, services, information; Koo \& Ju, 2010). Academics and practitioners of online shopping have noticed that atmospheric cues play an important role in encouraging and persuading desired consumer attitudes and behaviors (Eroglu, Machleit, \& Davis, 2003).

In the early works of Kotler (1974), consumers were said to respond to a "total product" perspective while making a purchase-decision rather than simply reacting to the product or service being offered. Kotler highlighted store atmosphere as one of the significant factors behind this perception. He defined store atmosphere as "the conscious designing of space to create a positive buying environment to produce specific emotional effects in the buyer that enhance purchasing probability" (p. 174). Several studies reported that the shopping atmosphere induces pleasure and arousal responses, and they, in turn, affect customers' approach and avoidance behavior toward the store (Baker, Parasuraman, Grewal, \& Voss, 2002; Grewal, Baker, Levy, \& Voss, 2003).

In a physical store, the atmosphere includes sensory cues such as color, lighting, music, and odor (Morrison, Gan, Dubelaar, \& Oppewal, 2011; Soars, 2009), but it is constrained in an online store (or an online shopping website), where only visual and auditory cues can be manipulated (Cheng, Wu, \& Yen, 2009; Im, Lennon, \& Stoel, 2010). The work of Eroglu, Machleit, and Davis (2001) and Wu, Cheng, and Yen (2008) offered some explanation to what exactly can designers of virtual settings manipulate - that is, in an online store, its store atmosphere, or the web atmospherics, can be manipulated by web designers to influence consumer behavior, and this includes all cues used for designing the website and its layout such as background color and pattern, hyperlinks, icons, interactive web applications, music, overall color scheme, typeface, and web borders. It was also noted that applying interactive features in the design of web atmospherics makes the web experience more dynamic.

Although the effects of atmospherics in traditional stores have been thoroughly and empirically studied, their effects on the online environment have been acknowledged to be very limited ( $\mathrm{Wu}$, Cheng, \& Yen, 2008). This study contributes by extending previous lines of inquiry on store atmospherics by examining the effects of web atmospherics on two types of online consumer behavior: Entertainment gratification and web irritation (see Figure 1). The following sections establish the conceptual links among web atmospherics, entertainment gratification, and web irritation.

\subsection{Entertainment Gratification}

Entertainment gratification in online shopping refers to the degree of enjoyment an individual gets from online shopping - it is the degree to which an online shopping site is fun and entertaining to online consumers (Lim \& Ting, 2012b). Existing studies suggest that entertainment is a hedonic component of online shopping that provides consumers with a means to escape boredom, find entertainment, and experience enjoyment (Luo, 2002; Wolfinbarger \& Gilly, 2001). This includes an evaluation of a website based on users' assessment of the amount of fun, playfulness, and pleasure they experience or anticipate from the website (Huang, 2003). 
Wan, Nan, and Smith (2009) show that online retailers who have a strong presence on the Internet are empowered with well-designed dynamic web atmospherics. That is, product or service information is neither just laid out there on the website nor is it organized by a simple navigation or site map; instead, consumers who visit the online shopping website are usually required to surf and "play" around in order to have a sense of site structure and to locate product information. This is supported by Kim, Fim, and Park (2010), who suggest that online consumers' need for aesthetic enjoyment, diversion, or emotional release can be met by using appealing site designs, such as interactive and graphical web designs. A more vivid site making an appropriate use of audio and animation is also said to create more positive online shopping experiences (Coyle \& Thorson, 2001). The work of Close and Kukar-Kinney (2010) lends further support by showing the enjoyment that online consumers experience when using interactive shopping carts - both web browsers and actual consumers enjoyed the active interaction of clicking and placing shopping items into their shopping cart compared to passively browsing items on the webpage. Thus, online retailers with well-designed dynamic web atmospherics are likely to succeed in persuading consumers to perceive the online shopping website to be enjoyable in its own right. On the basis of these assumptions, this study can propose the following hypothesis:

H1 Online retailers whose online shopping websites have well-designed dynamic web atmospherics will have a positive influence on entertainment gratification.

\subsection{Web Irritation}

Web irritation refers to the degree of annoyance felt by an individual, and in the case of online shopping it is the degree to which the online shopping site appears messy and irritating to online consumers (Lim \& Ting, 2012b). Existing studies suggest that web users' feeling of irritation may be caused by tactics perceived to be annoying, offensive, insulting, or overly manipulative, which ultimately reduce marketing effectiveness (Azeem, 2012; Gao \& Koufaris, 2006). Gao and Koufaris (2006) maintain that web irritation can be in the form of web users' feelings of confusion, distraction, and frustration due to the way a website is presented in terms of its web structure, navigation, function, or design elements.

Ducoffe (1996) shows that poorly designed web atmospherics often makes inappropriate use of web banners. For example, scattered web and pop-up banners may exacerbate human anxiety, distract consumers' attentions, and dilute human experiences. Similarly, Edward, Li, and Lee (2002) looked at pop-up advertisements and interstitials (with the effects of their timing) and concluded that online consumers were most annoyed when advertisements interrupted tasks as opposed to when they were timed to occur between activities. Luo (2002) adds that online retailers who create web designs that are too flashy with big-size graphics may lead to unwanted, offending, and negative influence. Misuse of interactive web applications on online shopping websites that spam and intrude on consumers' privacy and stifle consumer acceptance can also lead to possible annoyance among online consumers (Azeem, 2012). While these studies did not look at web atmospherics as a research construct, their findings illustrate an obvious case of poorly designed web atmospherics. In the light of this, this study proposes the following hypothesis:

H2 Online retailers whose online shopping websites have well-designed dynamic web atmospherics will have a negative influence on web irritation.



Figure 1. Conceptual model 


\section{Methods}

This study tested its propositions using survey data collected from self-administered questionnaires. A target of 300 usable responses was obtained using systematic sampling from approximately 850 encounters with consumers at simple randomly selected shopping malls in Klang Valley, Malaysia (see Lim \& Ting (2012c) for simple random and systematic sampling procedures). A screening question was asked to identify consumers who had made an online purchase within the past 12 months to ensure that participants of this study had the necessary experience to evaluate the items measuring the research constructs. Questionnaires were distributed during low-, medium-, and high-peak shopping hours and days over a four-week period. Respondents participating in this study received no incentives, making their participation voluntary. It took about an average of 20 minutes for each participant to complete the survey, which was part of a larger study.

The questionnaire had two parts. In the first part, participants were required to indicate their responses to seven socio-demographic questions concerning gender, age, marital status, income, occupation, highest academic qualification, and race. In the second part, they were asked to indicate their responses to twelve 5-point Likert scaled questions measuring the research constructs for this study. All questions were adopted from existing marketing and information systems studies (see Table 1). Collected data were analyzed using SPSS v.18 (for descriptive analysis, reliability testing, and exploratory factor analysis) and AMOS v.18 (for confirmatory factor and path analyses).

Table 1. Source of measurement items

\begin{tabular}{llll}
\hline Factors & $\begin{array}{l}\text { Number } \\
\text { items }\end{array}$ & of measurement & Sources \\
\hline $\begin{array}{l}\text { Entertainment } \\
\text { gratification }\end{array}$ & 4 & $\begin{array}{l}\text { Chen, Gillenson, and Sherrell (2002); Ducoffe } \\
(1996) .\end{array}$ \\
Web irritation & 4 & Ducoffe (1996); Korgaonkar and Wolin (1999). \\
Web atmospherics & 4 & Koo and Ju (2010). \\
\hline
\end{tabular}

\section{Analyses and Results}

\subsection{Sample Description}

Of the 300 online consumers who participated in the survey, over $68 \%$ were female. The participants' age ranged in age from 18 to $51 ; 56 \%$ of the participants were between 21 and 30 years of age. About $61 \%$ were single, $35 \%$ were married, while the remaining were divorced. In terms of income, most participants were in a combined income range of RM2,000 and RM4,000 (USD $\$ 1=\mathrm{RM} 3.33$ as of 20 August 2013). In terms of employment, approximately three quarters of the participants were full time employees. Fifty-two percent had undergraduate qualifications, $8 \%$ held postgraduate degrees, and the rest had studied up to high school. Lastly, as for race, $53 \%$ of the participants were Chinese, $41 \%$ Malays, and $6 \%$ Indians. As a whole, the findings are similar to those of Alam, Bakar, Ismail, and Ahsan (2008), who looked at the current population of Malaysian Internet users.

\subsection{Exploratory Factor Analysis}

The dimensionality of the research constructs under study was examined using exploratory factor analysis in SPSS v.18. The results of the analysis presented three factors with eigenvalues greater than 1 , explaining $78 \%$ of the variance. All items loaded strongly on each factor (above 0.5). No cross-loadings were found. In general, factor loadings for each item ranged from .84 to .95 . Table 2 presents the final set of research constructs and its corresponding measurement items.

\subsection{Confirmatory Factor Analysis}

From the exploratory factor analysis, the identified factor structures were then validated using confirmatory factor analysis in AMOS v.18 (see Table 2). Results of the confirmatory factor analysis indicate satisfactory support for the three dimension model $\left(\chi^{2}(300)=102.05, p<0.000 ; \chi^{2} / d f\right.$ ratio $=2.08$; GFI $=.95$; CFI $=.99$; TLI $=.99$; RMSEA $=.06$ ). All factor loadings associated with each of the eight dimensions exceeded .60 and the $\mathrm{t}$-values of all indicator loadings exceeded the critical values at the .05 significance level (Hair, Anderson, Tatham, William, \& Black, 1998). 
Table 2. Factor analysis

\begin{tabular}{|c|c|c|c|c|}
\hline \multirow{2}{*}{ Factors and items } & \multirow{2}{*}{$\begin{array}{c}\text { Mean } \\
\text { (SD) }\end{array}$} & \multicolumn{2}{|c|}{ Factor loading } & \multirow{2}{*}{$\begin{array}{c}\text { Cronbach's } \\
\alpha\end{array}$} \\
\hline & & Exploratory & Confirmatory & \\
\hline Entertainment gratification & & & & .92 \\
\hline I find it entertaining to shop at online retailers. & $\begin{array}{l}3.77 \\
(.86)\end{array}$ & .93 & .86 & \\
\hline I find that online shopping sites are fun to use. & $\begin{array}{l}3.73 \\
(.90)\end{array}$ & .95 & .89 & \\
\hline I feel excited when I shop online. & $\begin{array}{l}4.01 \\
(.95)\end{array}$ & .87 & .75 & \\
\hline $\begin{array}{l}\text { Using online shopping sites to purchase } \\
\text { products provide me with lots of enjoyment. }\end{array}$ & $\begin{array}{l}4.00 \\
(.88)\end{array}$ & .86 & .74 & \\
\hline Web irritation & & & & .96 \\
\hline I often feel irritated when shopping online. & $\begin{array}{c}1.64 \\
(1.33)\end{array}$ & .93 & .88 & \\
\hline $\begin{array}{l}\text { I feel that most online shopping sites are } \\
\text { confusing. }\end{array}$ & $\begin{array}{c}1.63 \\
(1.28)\end{array}$ & .93 & .89 & \\
\hline $\begin{array}{l}\text { I feel that most online shopping sites are } \\
\text { messy. }\end{array}$ & $\begin{array}{c}1.63 \\
(1.20)\end{array}$ & .92 & .88 & \\
\hline $\begin{array}{l}\text { I often feel frustrated when shopping at online } \\
\text { stores. }\end{array}$ & $\begin{array}{l}1.38 \\
(.68)\end{array}$ & .91 & .86 & \\
\hline Web atmospherics & & & & .90 \\
\hline $\begin{array}{l}\text { It is desirable for online shopping sites to have } \\
\text { dynamic graphics. }\end{array}$ & $\begin{array}{l}3.95 \\
(.97)\end{array}$ & .89 & .86 & \\
\hline $\begin{array}{l}\text { It is desirable for online shopping sites to have } \\
\text { interactive features. }\end{array}$ & $\begin{array}{l}3.90 \\
(.78)\end{array}$ & .84 & .76 & \\
\hline $\begin{array}{l}\text { It is desirable for online shopping sites to be } \\
\text { neatly designed. }\end{array}$ & $\begin{array}{l}3.75 \\
(.99)\end{array}$ & .88 & .84 & \\
\hline $\begin{array}{l}\text { It is desirable for online shopping sites to look } \\
\text { appealing. }\end{array}$ & $\begin{array}{c}4.22 \\
(1.02)\end{array}$ & .89 & .86 & \\
\hline
\end{tabular}

\subsection{Reliability and Validity Tests}

To assess the internal consistency for each research construct, a reliability test was performed by computing Cronbach's alphas $(\alpha)$. Results show that $\alpha$-values ranged from .90 to .96 , indicating high internal consistency for all three factors. Discriminant validity among the three factors was assessed by comparing correlations between research constructs. Results indicate that the correlation between constructs ranged from .48 to .69 , with the correlations of no pair of measures exceeding the criterion of .90 and above (see Table 3; Hair, Anderson, Tatham, William, \& Black, 1998). Thus, convergent and discriminant validity of measures are established.

Table 3. Correlation matrix

\begin{tabular}{llll}
\hline & EG & WI & WA \\
\hline EG & 1 & & \\
WI & $-.59^{* *}$ & 1 & \\
WA & $.51^{* *}$ & $-.56^{* *}$ & 1 \\
\hline
\end{tabular}

Note: ${ }^{* *}$ Correlation is significant at the $\overline{.01 \text { level (two-tailed); EG }=}$ entertainment gratification; WI = web irritation; WA = web atmospherics. 


\subsection{Structural Relationships of the Conceptual Model}

In order to examine the model fit and predictive capability of the three factor model (web atmospherics, entertainment gratification, and web irritation), structural equation modeling using the maximum likelihood technique was applied. The overall fit statistics suggest that the model has a reasonable model fit to the data $\left(\chi^{2}\right.$ $(300)=107.45, p<0.000 ; \chi^{2} / d f$ ratio $\left.=2.15 ; \mathrm{GFI}=.94 ; \mathrm{CFI}=.99 ; \mathrm{TLI}=.99 ; \mathrm{RMSEA}=.06\right)$. That is, all model fit indexes exceed their respective common acceptable levels. Table 4 lists the structural parameter estimates and the significance of the conceptual model. All conceptual links were found to be significant; thus, $\mathrm{H} 1$ and $\mathrm{H} 2$ are supported; the conceptual links among web atmospherics, entertainment gratification, and web irritation are empirically validated and supported.

Table 4. Results of estimation structural model

\begin{tabular}{llcc}
\hline Path to & Path from & Structural coefficients & $p$-value \\
\hline Entertainment gratification & Web atmospherics & $.37^{*}$ & .000 \\
Web irritation & Web atmospherics & $-.39^{* *}$ & .000 \\
\hline
\end{tabular}

Note: ${ }^{* *}$ Correlation is significant at the .01 level (two-tailed).

\section{Discussion}

This study extended the previous lines of inquiry on store atmospherics by investigating the effects of web atmospherics on entertainment gratification and web irritation. In general, the results from the structural model analysis support the propositions put forth by this study. This paper provides empirical evidence to support the conceptual links established among web atmospherics, entertainment gratification, and web irritation. That is, online shopping websites with dynamic and well-designed web atmospherics were empirically found to increase entertainment gratification and decrease web irritation among online consumers. These findings lend support to existing studies recommending the manipulation of web atmospherics to promote consumers' perceptions of entertainment and to prevent consumers' perceptions of annoyance on the Web.

Given this orientation, this study encourages online retailers to carefully design their online shopping websites. Online retailers can consider using dynamic graphics and interactive features to foster consumer feelings of enjoyment, entertainment excitement, and fun. More importantly, to avoid occurrences of confusion, frustration, messiness, and irritation, online retailers are reminded to ensure that the web atmospherics of their online shopping websites are always neat and appealing. Decisions and efforts to manipulate the atmospherics of online shopping websites in this way should, hopefully, help online retailers provide online consumers with entertainment gratification and reduce any risk of irritation and annoyance among them.

\section{Limitations and Future Research Directions}

While this study has addressed the theoretical gaps in the extant literature, its limitations open avenues for future research. First, this study examined web atmospheric as a single construct. Future research could test the effects of different web atmospheric cues, for example, color, lighting, music, and the different interactive web applications. Second, the findings of this study are limited to the context of online shopping websites. Future researches are encouraged to examine the effects of conceptual links established in this study on other industries using the Internet as a communication medium. For example, banking, education, and healthcare industries could benefit from understanding their target audience expectations of web atmospherics and how this would influence their degree of enjoyment and irritation while at visiting the websites. Lastly, this study did not test for individual differences (e.g., age, gender) between the effects of web atmospherics on entertainment gratification and web irritation. Investigation into these differences could help online retailers better understand their target market and work to improve elements of web atmospheric in accordance with the preferences of their targeted customers.

\section{References}

Ahuja, M., Gupta, B., \& Raman, P. (2003). An empirical investigation of online consumer purchasing behavior. Communications of the ACM, 46(12), 145-151. http://dx.doi.org/10.1145/953460.953494

Alam, S. S., Bakar, Z., Ismail, H. B., \& Ahsan, M. N. (2008). Young consumers online shopping: An empirical study. Journal of Internet Business, 5, 81-98. 
Azeem, M. A. (2012). Consumers attitudes toward commercial e-mail spam and web pop-ups: interference, perceived loss of control, and irriation. Information and Knowledge Management, 2(1), 21-33.

Baker, J., Parasuraman, A., Grewal, D., \& Voss, G. B. (2002). The influence of multiple store environment cues on perceived merchandise value and patronage intentions. Journal of Marketing, 66(2), 120-141. http://dx.doi.org/10.1509/jmkg.66.2.120.18470

Baymard Institute (2013, July 8). Cart abandonment rate statistics. Retrieved August 19, 2013, from Baymard Institute: http://baymard.com/lists/cart-abandonment-rate

Bridges, E., \& Florsheim, R. (2008). Hedonic and utilitarian shopping goals: the online experience. Journal of Business Research, 61(4), 309-314. http://dx.doi.org/10.1016/j.jbusres.2007.06.017

Chang, E. C., \& Tseng, Y. F. (2011). Research note: e-store image, perceived value and perceived risk. Journal of Business Research, 66(7), 864-870. http://dx.doi.org/10.1016/j.jbusres.2011.06.012

Chang, M. L., \& Wu, W. Y. (2012). Revisiting perceived risk in the context of online shopping: an alternative perspective of decision-making styles. Psychology and Marketing, 29(5), 378-400. http://dx.doi.org/10.1002/mar.20528

Chen, L. D., Gillenson, M. L., \& Sherrell, D. L. (2002). Enticing online consumers: an extended technology $\begin{array}{llll}\text { acceptance perspective. Information and } & \text { Management, 39(8), }\end{array}$ http://dx.doi.org/10.1016/S0378-7206(01)00127-6

Cheng, F. F., Wu, C. S., \& Yen, D. C. (2009). The effect of online store atmosphere on consumer's emotional responses - an experimental study of music and color. Behavior and Information Technology, 28(4), 323-334. http://dx.doi.org/10.1080/01449290701770574

Cheung, C. M., Chiu, P. Y., \& Lee, M. K. (2011). Online social networks: why do students use facebook? Computers in Human Behavior, 27(4), 1337-1343. http://dx.doi.org/10.1016/j.chb.2010.07.028

Close, A. G., \& Kukar-Kinney, M. (2010). Beyond buying: motivations behind consumers' online shopping cart use. Journal of Business Research, 63(9), 986-992. http://dx.doi.org/10.1016/j.jbusres.2009.01.022

Coyle, J. R., \& Thorson, E. (2001). The effects of progressive levels of interactivity and vividness in web marketing sites. Journal of Advertising, 30(3), 65-77. http://dx.doi.org/10.1080/00913367.2001.10673646

Darley, W. K., Blankson, C., \& Luethge. (2010). Toward an integrated framework for online consumer behavior and decision making process: A review. Psychology and Marketing, 27(2), 94-116. http://dx.doi.org/10.1002/mar.20322

Ducoffe, R. H. (1996). Advertising value and advertising on the web. Journal of Advertising Research, 36(5), 21-35.

Eroglu, S. A., Machleit, K. A., \& Davis, L. M. (2001). Atmospheric qualities of online retailing: a conceptual model and implications. Journal of Business Research, 54(2), 177-184. http://dx.doi.org/10.1016/S0148-2963(99)00087-9

Eroglu, S. A., Machleit, K. A., \& Davis, L. M. (2003). Empirical testing of a model of online store atmospherics and shopper responses. Psychology and Marketing, 20(2), 139-150. http://dx.doi.org/10.1002/mar.10064

Gao, Y., \& Koufaris, M. (2006). Perceptual antecedents of user attitude in electronic commerce. Database for Advances in Information Systems, 37(2/3), 42-50. http://dx.doi.org/10.1145/1161345.1161353

Grewal, D., Baker, J., Levy, M., \& Voss, G. B. (2003). The effects of wait expectations and store atmosphere evaluations on patronage intentions in service-intensive retail stores. Journal of Retailing, 79(4), 259-268. http://dx.doi.org/10.1016/j.jretai.2003.09.006

Ha, S., \& Stoel, L. (2009). Consumer e-shopping acceptance: antecedents in a technology acceptance model. Journal of Business Research, 62(5), 565-571. http://dx.doi.org/10.1016/j.jbusres.2008.06.016

Hair, J. F., Anderson, R. E., Tatham, R. L., \& Black, W. C. (1998). Multivariate data analysis. Upper Saddle River, NJ: Prentice-Hall.

Hausman, A. V., \& Siekpe, J. S. (2009). The effect of web interface features on consumer online purchase intentions. Journal of Business Research, 62(1), 5-13. http://dx.doi.org/10.1016/j.jbusres.2008.01.018

Hernandez, B., Jimenez, J., \& Martin, M. J. (2010). Customer behavior in electronic commerce: the moderating effect of e-purchasing experience. Journal of Business Research, 63(9), 964-971. http://dx.doi.org/10.1016/j.jbusres.2009.01.019 
Hess, T., Lang, K. R., \& Xu, S. X. (2011). Social embeddedness and online consumer behavior. Electronic Markets, 21(3), 157-159. http://dx.doi.org/10.1007/s12525-011-0071-1

Hoffman, D. L., \& Novak, T. P. (2009). Flow online: lessons learned and future prospects. Journal of Interactive Marketing, 23(1), 23-34. http://dx.doi.org/10.1016/j.intmar.2008.10.003

Huang, E. (2008). Use and gratification in e-consumers. Internet Research, 18(4), 405-426. http://dx.doi.org/10.1108/10662240810897817

Im, H., Lennon, S. J., \& Stoel. (2010). The perceptual fluency effect on pleasurable online shopping experience. Journal of Research in Interactive Marketing, 4(4), 280-295. http://dx.doi.org/10.1108/17505931011092808

Jing, X., \& Xie, J. (2011). Group buying: a new mechanism for selling through social interactions. Management Science, 57(8), 1354-1372. http://dx.doi.org/10.1287/mnsc.1110.1366

Kim, D. J., Ferrin, D. L., \& Rao, H. R. (2008). A trust-based consumer decision-making model in electronic commerce: the role of trust, perceived risk, and their antecedents. Decision Support Systems, 44(2), 544-564. http://dx.doi.org/10.1016/j.dss.2007.07.001

Kim, J. U., Kim, W. J., \& Park, S. C. (2010). Consumer perceptions on web advertisements and motivation factors to purchase in the online shopping. Computers in Human Behavior, 26(5), 1208-1222. http://dx.doi.org/10.1016/j.chb.2010.03.032

Ko, H., Cho, C. H., \& Roberts, M. S. (2005). Internet uses and gratifications: a structural equation model of $\begin{array}{llll}\text { interactive advertising. Journal of } & \text { Advertising, }\end{array}$ http://dx.doi.org/10.1080/00913367.2005.10639191

Koo, D. M., \& Ju, S. H. (2010). The interactional effects of atmospherics and perceptual curiosity on emotions and online shopping intention. Computers in Human Behavior, 26(3), 377-388. http://dx.doi.org/10.1016/j.chb.2009.11.009

Kotler, P. (1973). Atmospherics as a marketing tool. Journal of Retailing, 49(4), 48-64.

Leighton, T. (2009). Improving performance on the Internet. Communications of the ACM, 52(2), 44-51. http://dx.doi.org/10.1145/1461928.1461944

Lian, J. W., \& Lin, T. M. (2008). Effects of consumer characteristics on their acceptance of online shopping: comparisons among different product types. Computers in Human Behavior, 24(1), 48-65. http://dx.doi.org/10.1016/j.chb.2007.01.002

Lim, W. M. (2013). Toward a theory of online buyer behavior using structural equation modeling. Modern Applied Science, 7(10), 34-41. http://dx.doi.org/10.5539/mas.v7n10p34

Lim, W. M., \& Ting, D. H. (2012a). E-shopping: an analysis of the technology acceptance model. Modern Applied Science, 6(4), 49-62. http://dx.doi.org/10.5539/mas.v6n4p49

Lim, W. M., \& Ting, D. H. (2012b). E-shopping: an analysis of the uses and gratifications theory. Modern Applied Science, 6(5), 48-63. http://dx.doi.org/10.5539/mas.v6n5p48

Lim, W.M., \& Ting, D. H. (2012c). Research methodology: a toolkit of sampling and data analysis techniques for quantitative research. GRIN Publishing: Munich, Germany.

Luo, X. (2002). Uses and gratifications theory and e-consumer behaviors: a structural equation modeling study. Journal of Interactive Advertising, 2(2), 44-54. http://dx.doi.org/10.1080/15252019.2002.10722060

Morrison, M., Gan, S., Dubelaar, C., \& Oppewal, H. (2011). In-store music and aroma influences on shopper behavior and satisfaction. Journal of Business Research, 64(6), 558-564. http://dx.doi.org/10.1016/j.jbusres.2010.06.006

Mulhern, F. (2009). Integrated marketing communications: from media channels to digital connectivity. Journal of Marketing Communications, 15(2/3), 85-101. http://dx.doi.org/10.1080/13527260902757506

Nielsen, J. (2000). Designing web usability: the practice of simplicity. Indianapolis, IN: New Riders Publishing.

Scarpi, D. (2012). Work and fun on the internet: the effects of utilitarianism and hedonism online. Journal of Interactive Marketing, 26(1), 53-67. http://dx.doi.org/10.1016/j.intmar.2011.08.001

Singh, D., Bansal, M., \& Kaur, N. (2012). Internet retailing - new era of marketing. International Journal of Marketing and Technology, 2(3), 154-169. 
Soars, B. (2009). Driving sales through shoppers' sense of sound, sight, smell and touch. International Journal of Retail and Distribution Management, 37(3), 286-298. http://dx.doi.org/10.1108/09590550910941535

Srinivasan, S. S., Anderson, R., \& Ponnavolu, K. (2002). Customer loyalty in e-commerce: an exploration of its antecedents and consequences. Journal of Retailing, 78(1), 41-50. http://dx.doi.org/10.1016/S0022-4359(01)00065-3

Suh, J. C., \& Yi, Y. (2012). Do consumption goals matter? The effects of online loyalty programs in the $\begin{array}{llll}\text { satisfaction-loyalty relation. Psychology and } & \text { Marketing, 29(8), 549-557. }\end{array}$ $\mathrm{http}: / / \mathrm{dx}$.doi.org/10.1002/mar.20542

Szabo, G., \& Huberman, B. A. (2010). Predicting the popularity of online content. Communications of the ACM, 53(8), 80-88. http://dx.doi.org/10.1145/1787234.1787254

Wan, F., Nan, N., \& Smith, M. C. (2009). Consumers optimal experience on commercial web sites: a congruency effect of web atmospheric design and consumers' surfing goal. In S. Bandyopadhyay (Ed.), Contemporary Research in E-Branding (pp. 78-94). Pennsylvania: IGI Global.

Wolfinbarger, M., \& Gilly, M. C. (2001). Shopping online for freedom, control, and fun. California Management Review, 43(2), 34-55. http://dx.doi.org/10.2307/41166074

Wu, C. S., Cheng, F. F., \& Yen, D. C. (2008). The atmospheric factors of online storefront environment design: an empirical experiement in Taiwan. Information and Management, 45(7), 493-498. http://dx.doi.org/10.1016/j.im.2008.07.004

$\mathrm{Wu}$, S. I. (2003). The relationship between consumer characteristics and attitude toward online shopping. Marketing Intelligence and Planning, 21(1), 37-44. http://dx.doi.org/10.1108/02634500310458135

\section{Copyrights}

Copyright for this article is retained by the author(s), with first publication rights granted to the journal.

This is an open-access article distributed under the terms and conditions of the Creative Commons Attribution license (http://creativecommons.org/licenses/by/3.0/). 